\title{
A REVIEW OF THE GEOLOGY OF KIMBERLITE PIPES OF THE EKATI PROPERTY, NORTHWEST TERRITORIES, CANADA
}

\author{
Tom Nowicki ${ }^{1}$, Barbara Crawford ${ }^{2}$, Darren Dyck ${ }^{2}$, Jon Carlson ${ }^{2}$, Ross McElroy ${ }^{3}$, Herb \\ Helmstaedt ${ }^{4}$ and Peter Oshust ${ }^{2}$ \\ ${ }^{1}$ Mineral Services Canada Inc, Vancouver, Canada $;{ }^{2}$ BHP Billiton Diamonds Inc., Kelowna, Canada $;{ }^{3}$ BHP Billiton \\ Diamonds Inc., Yellowknife, Canada $;{ }^{4}$ Queens University, Kingston, Canada.
}

\section{INTRODUCTION}

The Ekati property is located in the central part of the Slave Structural Province of the Canadian Shield and occupies a claim block of approximately $1800 \mathrm{~km}^{2}$. It encompasses the BHP Billiton Ekati diamond mine and includes approximately 150 kimberlites that form a significant proportion of the Lac de Gras kimberlite field. With few exceptions, these have been intersected by at least one diamond drill hole and, for a significant number of pipes, extensive delineation drilling and / or development has been undertaken, providing a large amount of information relating to the geological characteristics of these intrusions. This work has shown that, in several respects, these bodies do not conform to current models of kimberlite pipe emplacement and geology. In this review, the geological characteristics of the Ekati kimberlites are presented with specific reference to key localities on the property. The morphology, lithologies and internal geology of these pipes are discussed with a view to better constraining emplacement models for these and other Lac de Gras style kimberlites.

\section{GEOLOGICAL SETTING}

The bedrock geology of the Ekati property comprises metamorphosed supracrustal rocks (greywackemudstone turbidites, now predominantly mica schist) that are intruded by syn- to post-tectonic plutons, predominantly of granite, granodiorite and tonalite. In addition, five Proterozoic mafic dyke swarms, ranging in age from ca. 2.23 to $1.27 \mathrm{Ga}$ (Kjarsgaard, 2001 and references cited therein) intrude the area.

No Phanerozoic cover rocks are currently preserved in the Lac de Gras region, but fossil-bearing shale xenoliths within the kimberlites indicate that a sedimentary cover sequence was present at the time of emplacement. Palynology studies indicate predominantly early Paleocene and late Cretaceous ages (Nassichuk and McIntyre, 1996). Thermal maturity studies on shale inclusions from kimberlite indicate that up to $1,500 \mathrm{~m}$ of late Cretaceous and early Tertiary strata were present at some time prior to kimberlite eruption (Stasiuk et al., 2003). However, preservation of bedded, wood-bearing volcaniclastics to depths of several hundreds of meters within the pipes at Ekati suggests that the Cretaceous / Tertiary cover was significantly thinner at the time of kimberlite emplacement. The nature of late Cretaceous and Paleocene palynmorphs as well as the presence of wood, leaves, and turtle bones within the Ekati kimberlites indicates that they were emplaced into a humid, temperate, terrestrial environment.

\section{KIMBERLITE DISTRIBUTION AND AGE}

Kimberlites represent the only signs of Phanerozoic igneous activity on the Ekati property. Although they occur in most Archean rock types, the kimberlites show an apparent preference for plutonic hosts. They are associated with lineaments of varying orientations, with intersections of two or more lineaments, and of lineaments with dykes. They also occur along dykes, along jogs in dykes, and at intersections of two or more dykes or dyke sets.

Dating of more than 30 kimberlites at Ekati by $\mathrm{Rb}-\mathrm{Sr}$ and $\mathrm{U}-\mathrm{Pb}$ methods indicates a range of emplacement ages from ca. 45 to $75 \mathrm{Ma}$, with four apparent age groupings evident at $48 \mathrm{Ma}, 52-53 \mathrm{Ma}, 55 \mathrm{Ma}, 58.5 \mathrm{Ma}$ and 64-66 Ma, respectively (Creaser et al., 2003).

\section{INTRUSION MORPHOLOGY}

Most of the 150 Ekati kimberlites discovered to date are pipes, usually with the steep (75 to $85^{\circ}$ ), inward tapering sides typically associated with volcanic diatremes. In detail, however, pipe morphologies are highly variable and features such as outward dipping (overhanging) side walls, and elongate and irregular, often fault controlled, pipe geometries are common. The kimberlites are mostly small, with surface areas generally not exceeding 5 ha (mostly range from 0.1 to 
ca. $3 \mathrm{ha}$ ) but rare larger pipes (up to $16 \mathrm{ha}$ ) are present. Most of the kimberlites form discrete, single pipe intrusions. One known exception to this is the Misery pipe which occurs within a complex of multiple, apparently overlapping intrusions (Mustafa et al., 2003). Where deep drilling has been carried out, pipe depths of 400 to $600 \mathrm{~m}$ have been established. Although the size of the pipe is considerably reduced at depth (e.g. ca. $20 \mathrm{~m}$ diameter of Panda at $550 \mathrm{~m}$ below surface) and the pipe morphologies become less regular, drilling undertaken to date does not provide any clear evidence for complex root zones as described in the classic southern African kimberlite model (e.g. Field and Scott Smith, 1999). While zones rich in country rock xenoliths / blocks are fairly common adjacent to pipe margins within kimberlites, wall rocks are typically not brecciated. Narrow (mostly $<1 \mathrm{~m}$ ) kimberlite dykes are common on the periphery of and, in some cases, adjacent to pipes but never transecting / intruding them.

\section{KIMBERLITE LITHOLOGIES}

In most cases, the kimberlite pipes at Ekati are entirely occupied by a range of volcaniclastic lithologies (VK) and associated, generally relatively minor, fine-grained sediments. In certain localities, however, magmatic kimberlite is an important or dominant phase. The main kimberlite types encountered at Ekati are described below.

\section{MUD-RICH, RESEDIMENTED VOLCANICLASTIC KIMBERLITE (MRVK)}

This is dark, generally massive to crudely bedded, poorly sorted, matrix supported volcaniclastic kimberlite with variable concentrations of fresh to pervasively serpentinised, commonly angular olivine crystals, scattered mudstone and wall-rock xenoliths, and minor amounts of fresh to carbonized wood fragments set in a dark, friable, very fine-grained, clastic matrix dominated by probable disaggregated mud (Figure 1a). The mudstone clasts are predominantly small $(<10 \mathrm{~mm})$ with shapes ranging from rounded to angular. Irregular, plastically deformed and partially disaggregated mudstone clasts are common. Wall-rock xenoliths (mostly granitoids) rarely exceed ca. $5 \%$ of the rock. Juvenile lapilli are rare or absent in MRVK but small (generally $<4 \mathrm{~mm}$ ) clasts of partially lithified fine-grained $\mathrm{VK}$ and rare possible accretionary lapilli are present. Angular to subrounded quartz is a common, but not ubiquitous constituent. When present, bedding is defined primarily by variations in coarse olivine abundance, and crudely developed grading is relatively common.

\section{OLIVINE-RICH VOLCANICLASTIC KIMBERLITE (OVK)}

This variety of kimberlite is characterised by very high concentrations of olivine crystals. Examples are generally pale yellowish brown to grey, closely packed (often clast supported) and commonly display well developed bedding on scales ranging from meters to millimeters. Scattered small mudstone clasts (as described above) and wall-rock xenoliths are ubiquitous but, as in the case of MRVK, rarely exceed $5 \%$ of the rock. Juvenile lapilli are also rare but "autoliths" of fine-grained VK are common. The matrix of OVK consists primarily of fine-grained disaggregated mud or altered kimberlitic ash with varying proportions if micro- to cryptocrystalline serpentine. Bedding in these rocks is defined by variation in the grain size and abundance of olivine. OVK can occur in association with and grade into MRVK, but the distinctive, extremely olivine-rich, variety with finely bedded zones (Figure 1b) appears to represent a different lithological association, reflecting different depositional processes. The high olivine content and low ash / mud content of these materials implies efficient removal of fines during eruption and / or subsequent resedimentation.

\section{CRATER SEDIMENTS (EPICLASTICS)}

A range of different fine-grained, olivine-poor sedimentary rocks occur within many of the Ekati pipes. These typically occur as a minor component associated with both MRVK and OVK, but in certain cases (e.g. Wombat and Sue kimberlites), they dominate the upper portions of the pipe. The dominant sedimentary lithologies encountered are grey to brownish-grey siltstone, black, organic-rich mudstone and less common, fine- to medium-grained quartz sandstones. In general, these lithologies are dominated by material believed to have been derived from unconsolidated surface sediments present at the time of kimberlite eruption, but they also include varying amounts of fine-grained kimberlitic components (probable altered phlogopite, small olivine fragments and rare indicator minerals).

\section{JUVENILE-RICH, PRIMARY VOLCANICLASTIC KIMBERLITE (PVK)}

This is competent olivine-rich volcaniclastic kimberlite (Figure 1d) characterised by a relatively uniform macroscopic texture, a paucity of bedding features and the presence of abundant juvenile lapilli. It is generally 
coarse to very coarse-grained, but medium-grained varieties are evident in certain pipes. It contains relatively minor concentrations (mostly $\leq 5 \%$ ) of unaltered shale clasts and variable amounts of wall-rock xenoliths, commonly with increased abundances near the pipe margins where breccias are commonly encountered. Rare wood fragments are present. Juvenile lapilli are usually cored by large olivine crystals or country-rock clasts and typically display wide rims $(0.1$ to $>1 \mathrm{~mm})$ of fine- to very fine-grained, microphenocrystic magmatic kimberlite. The lapilli are generally rounded but also display elongate and irregular shapes. The PVK matrix is dominated by very fine-grained serpentine. The mud /ash material that is prevalent in the VK lithologies described above is either absent or present as a minor matrix component. In certain pipes, however, there appear to be gradational contacts between the PVK and overlying RVK material, resulting in the incorporation of significant amounts of mud into the PVK matrix. PVK typically occurs in the deeper portions of pipes, either interbedded with other $\mathrm{VK}$ varieties or as a massive phase that occupies the entire pipe at depth.

\section{TUFFISITIC KIMBERLITE (TK)}

A distinctive fragmental kimberlite type occurs within the lower portion of the Fox kimberlite. The mode of formation of this material is not certain, but it is clearly different to other VK types at Ekati and shows strong similarities to tuffisitic kimberlite described for southern African kimberlites (e.g. Field and Scott Smith, 1999). On this basis, this kimberlite type has been tentatively classified as tuffisitic kimberlite. The TK at Fox is a highly fragmental and intensely clayaltered kimberlite with a speckled macroscopic appearance (Figure 1c) stemming from very high concentrations (generally $>30 \%$ ) of altered, finely comminuted $(<4 \mathrm{~mm})$ granodiorite. The rock is relatively close-packed and contains moderate amounts (15 to $30 \%$ ) of pervasively serpentinised (and clay altered), coarse-grained (up to $5 \mathrm{~mm}$ ) olivine. Larger granodiorite xenoliths $(>4 \mathrm{~mm})$ vary in size and abundance but consistently comprise a minimum of $5 \%$ of the rock. Samples from less altered portions of this phase indicate that the matrix is dominated by finegrained serpentine but includes relatively abundant microlites of probable clinopyroxene. The lapilli are mostly rounded and typically display narrow $(<0.1 \mathrm{~mm})$ selvages, commonly overgrown by very fine-grained microlitic clinopyroxene. Probable autoliths of magmatic kimberlite are common. Rounded to irregularly-shaped clasts of fine-grained probable RVK are present in places and rare fossil wood fragments occur in the upper TK zone.

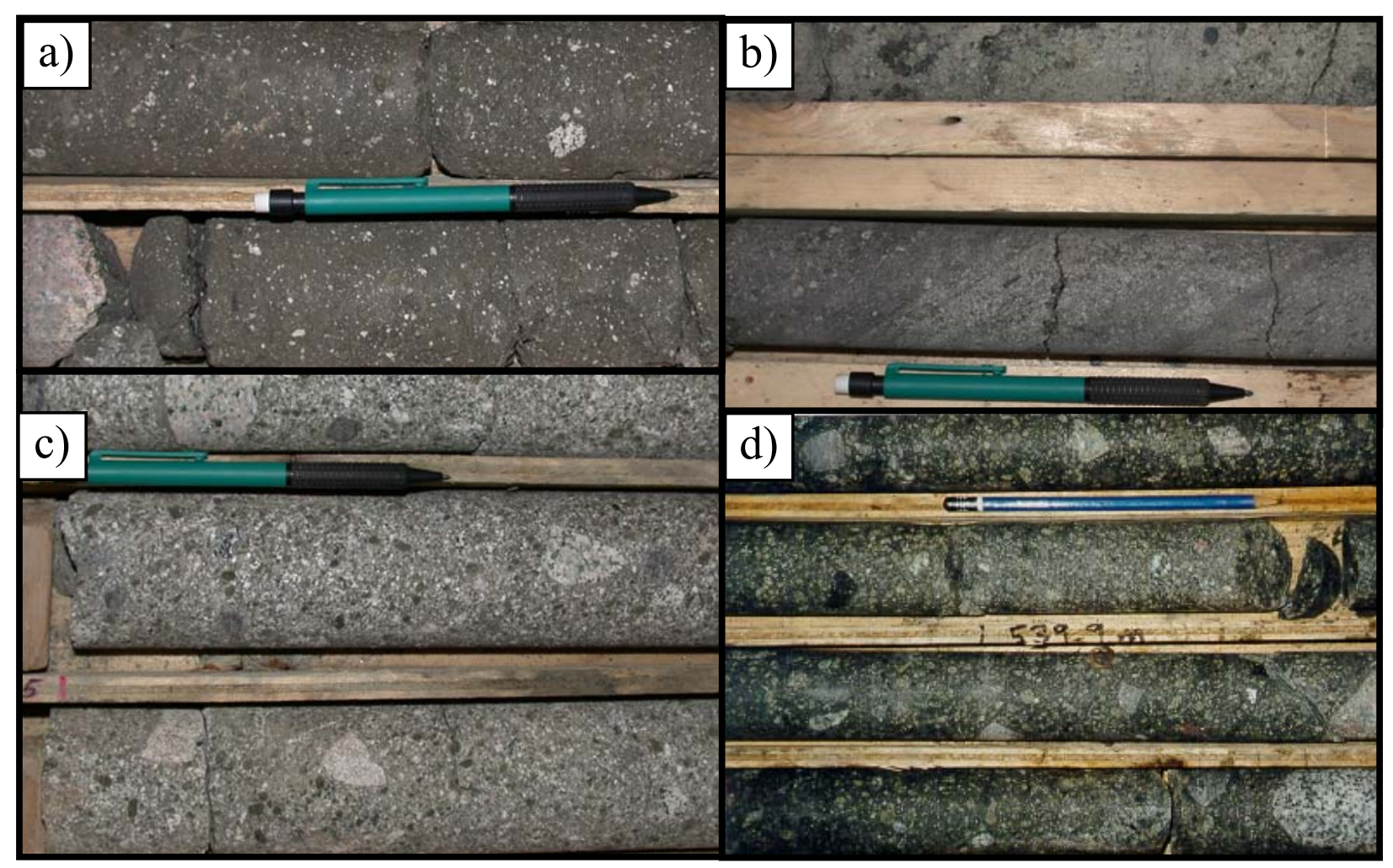

Figure 1: Examples of the main volcaniclastic kimberlite varieties observed at Ekati: a) massive, mud-rich RVK; b) massive (top) and finely bedded (bottom) olivine-rich VK; c) tuffisitic kimberlite; c) juvenile-rich, primary volcaniclastic kimberlite. 


\section{MAGMATIC KIMBERLITE (MK)}

Magmatic kimberlite occurs both as small peripheral dykes and as large intrusions that dominate or entirely occupy pipe-shaped bodies. This material is typical macrocrystic hypabyssal group 1 kimberlite. Minor amounts of aphanitic kimberlite are present in certain dyke intersections. The matrix of these rocks consists of variably serpentinised microphenocrystic olivine in a fine-grained groundmass including abundant very finegrained opaques and scattered perovskite. The matrix mineralogy is somewhat variable, but all of the large, pipe-filling intrusions are monticellite kimberlites. The mineralogy of $\mathrm{MK}$ dykes is more variable with monticellite, phlogopite-carbonate and serpentinecarbonate kimberlites observed in thin section. Matrix textures are typically uniform but segregationary and rare globular segregationary varieties are present.

\section{PIPE GEOLOGY MODELS}

The internal geology of the Ekati pipes is highly variable. Most of the pipes are overwhelmingly dominated by the variably bedded, xenolith-poor volcaniclastic kimberlite varieties described above, often to depths in excess of $400 \mathrm{~m}$. Tuffisitic kimberlite or kimberlite breccia is rare with possible examples recognized only at the Fox kimberlite and a small intrusion adjacent to Misery. Hypabyssal (magmatic) kimberlite occurs primarily as volumetrically insignificant narrow dykes, as described above. However, at a few localities, a large proportion of the pipe is occupied by magmatic kimberlite. Aspects of the internal geology of some specific Ekati kimberlites are described below to illustrate some of the variations observed.

\section{KOALA}

The Koala kimberlite is occupied by a sub-horizontally layered sequence of distinctive volcaniclastic kimberlite units. These display well-defined contacts that, in most cases, can be correlated across the pipe, allowing construction of a three-dimensional model of the pipe's internal geology (Figure 2). The phases identified at Koala include (from top to bottom): an upper layer of black mudstone (not modeled as part of the Koala resource); a thick zone of largely continuous graded material ranging from homogeneous fine-grained silty to sandy kimberlite with abundant exotic sediment (quartz and mud) to very coarse-grained, olivine-rich juvenile dominated VK at the base (Phase 1 and 2); a zone of intermixed mud-rich and olivine-rich resedimented volcaniclastic kimberlite (Phase 3); a distinctive siltstone marker unit characterized by abundant small wood fragments; a very thick mud/ashrich RVK unit; and a lowermost phase of olivine- and juvenile lapillus-rich PVK.

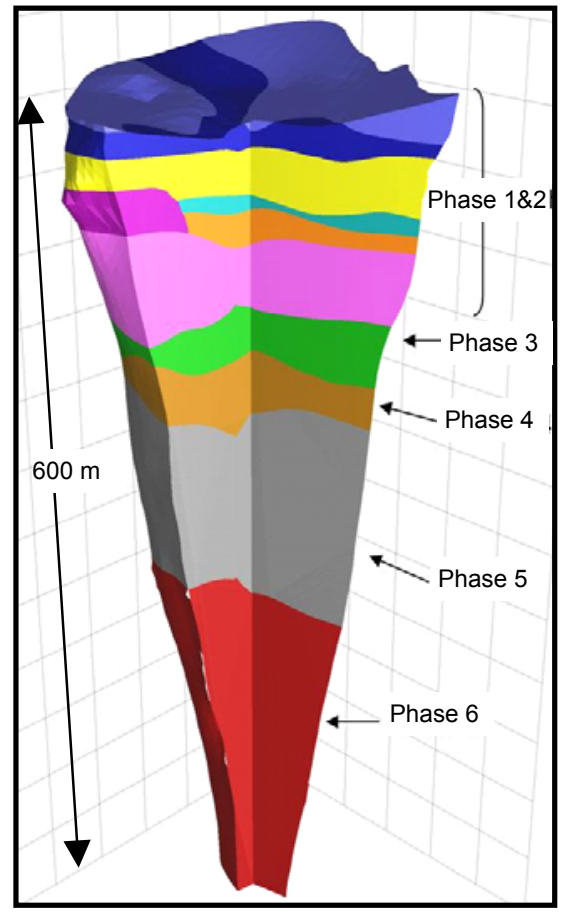

Figure 2: Cut-away 3-D model of the Koala kimberlite.

\section{PANDA}

Panda is geologically complex and includes numerous, discontinuous, highly variable, predominantly olivinerich volcaniclastic kimberlite units (OVK), with lesser amounts of MRVK and only minor beds of epiclastic material. The VK units within Panda are generally steeply dipping and do not form laterally or vertically continuous phases. The OVK units are crystaldominated and often clast supported, with relatively minor amounts of mud present. Bedding is defined by varying olivine content, grain size and, in particular, by varying proportions of dark fine-grained matrix material. While the observed textural and bedding features may reflect resedimentation processes, it is possible that some units represent minimally reworked pyroclastic material that has slumped en masse into the Panda pipe. In contrast, the MRVK material is likely to have been deposited by debris flow processes. Juvenilerich $P V K$ is evident in several of the deeper intersection of the pipe. It is interbedded with VK similar to that occurring in the upper portions of the kimberlite and contacts between these lithologies are typically sharp. 


\section{FoX}

The Fox kimberlite comprises an upper, slightly flared zone (100 to $150 \mathrm{~m}$ thick) infilled with MRVK very similar to that observed in other Ekati kimberlites, underlain by a diatreme shaped zone occupied by comparatively homogeneous tuffisitic kimberlite, as described above. The contact between these phases is sharp with no evidence for intermixing of the two. A zone with abundant large granodiorite boulders occurs within the TK phase, at a depths of approximately $80 \mathrm{~m}$ below the base of the RVK phase.

\section{PIPES DOMINATED BY MAGMATIC KIMBERLITE}

Pipes filled or partially filled by magmatic kimberlite include Leslie, Grizzly, Pigeon, Arnie and Mark. In the case of Leslie, a small remnant of very altered volcaniclastic kimberlite (possible TK) is preserved on the margin of the pipe. At Pigeon, the MK underlies a thick zone $(80$ to $100 \mathrm{~m})$ of RVK. In both of these cases, the magmatic phase appears to represent a late stage intrusion that is emplaced into and partially displaces VK.

\section{KIMBERLITE EMPLACEMENT}

The geological characteristics of kimberlites at Ekati are broadly consistent with the two-stage emplacement model suggested by Kirkley et al., 1998. The presence of bedded RVK, with incorporated surficial material, at depth within the majority of kimberlites suggests excavation of the pipe to minimum depths of ca. 400 to $500 \mathrm{~m}$ prior to infilling with volcaniclastic material. The volcaniclastic kimberlite that currently occupies most of the pipes, is interpreted to have formed predominantly by resedimentation and varying degrees of reworking of pyroclastic kimberlite deposited in a tuff ring during eruption, mixed with varying amounts of surface sediment and organic material. Resedimentation processes were highly variable and likely included massive collapse and slumping of pyroclastic material with minimal reworking, talus slope processes and debris / mud flows. Deposition of primary volcaniclastic kimberlite, possibly as withinvent pyroclastic deposits formed by eruption column collapse, generally occurred in the early stages of pipe infilling, with intermittent eruptions causing interbedding of this material with RVK in certain pipes. Fine-grained epiclastic material (siltstone and mudstone) was deposited during quiescent periods, probably by subaqueous sedimentation processes. In certain cases, the kimberlite vents were filled or partially filled by late-stage intrusion of large volumes of magmatic material. The presence of VK material in two of these pipes suggests that they were at least partially filled prior to kimberlite magma intrusion.

The high degree of fragmentation of juvenile material in the Ekati kimberlites and the observation that the pipes were likely to have been excavated to depths of $500 \mathrm{~m}$ or more, are indicative of a violent eruption style. The absence of significant amounts of xenolithic country-rock material in most of the VK infilling the Ekati pipes indicates efficient clearing of the vent prior to infilling. Although phreatomagmatic processes may have played a role in emplacement and eruption of kimberlite at Ekati, it is suggested that initial eruption and pipe formation is likely to have been driven by magmatic processes, i.e. by explosive exsolution of volatiles (primarily $\mathrm{CO}_{2}$ ) from the kimberlite magma.

\section{REFERENCES}

Creaser, R.A., Grütter, H.S. and Carlson, J.A. 2003. Macrocrystal phlogopite $\mathrm{Rb}-\mathrm{Sr}$ dates for the Ekati province kimberlites, Slave Province, Canada: Evidence for multiple intrusive episodes in the Paleocene and Eocene. Abstracts of the 8IKC, Victoria, June 2003, this volume.

Field M. and Scott Smith B.H., 1999. Contrasting geology and near-surface emplacement of kimberlite pipes in southern Africa and Canada. In: Proc. 7IKC, Cape Town, 1999, 214-237.

Kirkley M.B., Kolebaba M.R., Carlson J.A., Gonzales A.M., Dyck D.R. and Dierker C. 1998. Kimberlite emplacement processes interpreted from Lac de Gras examples. In: Ext. Abstr. 7IKC, Cape Town, 1998.

Kjarsgaard, B.A., 2001. Lac de Gras Kimberlite Field, Slave Province, 1:250,000 geology map and descriptive notes. GSC Open File 3238.

Mustafa, J., Nowicki, T., Oshust, P., Dyck, D., Crawford, B., and Harrison, S., 2003. The geology of the Misery kimberlite, Ekati Diamond Mine $^{\mathrm{TM}}$, Canada. Abstracts of the 8IKC, Victoria, June 2003, this volume.

Nassichuk, W.W. and McIntyre, D.J., 1996. Fossils from diamondiferous kimberlites at Lac de Gras, N.W.T.: Age and paleogeography. In: LeChaminant, A.N., Richardson, D.G., Dilabio, R.N.W. and Richardson, K.A. (Eds.), Searching for Diamonds in Canada, Geological Society of Canada, Open File 3228, 43-46.

Stasiuk, L.D., Sweet, A.R. and Issler, D.R, 2003. Thermal and burial history of Mesozoic sedimentary cover sequence in Lac de Gras kimberlite field, Northwest Territories, Canada. Abstracts of the 8IKC, Victoria, June 2003, this volume.

Contact: T.E. Nowicki, 1300, 409 Granville Street,

Vancouver, B.C., Canada, V6C 1T2.

Email: tom.nowicki@mineralservices.com 